\title{
SS-085心理学ワールドにおけるジェンダー・イクォリティ
}

\author{
企画代表者, 話題提供者, 司会者: 青野 篤子 (福山大学) \\ 話題提供者: 坂田 桐子 (広島大学) \\ 話題提供者 : 葛西真記子\# (鳴門教育大学) \\ 指定討論者：田口久美子 (和洋女子大学)
}

あらゆる分野でのジェンダー・イクォリテイが課題となっている。心理学ワールドとは, 単に心理学 の知識体系を意味していない。心理学を研究し, 心理学を教え, 心理学を組織する人々の集合体でもあ る。何を研究するか, 何のために研究するかは, 個々の研究者の価值観だけでなく研究者が属する組織 の規範や社会の要請からも影響を受ける。また, ジェンダー・イクォリティは, 研究する人たちのジェ ンダー比率がただ等しいということだけではなく, 研究の内容や研究の方法がジェンダーの視点からみ て公正であるという意味をも含意する。心理学は他の学問と比較すると女性研究者の比率が高いが, 果 たしてジェンダー・イクォリテイが達成されていると言えるのだろうか。このシンポでは, 日本の心理 学ワールドの現状と課題を, 組織論の観点から, また米国の心理学ワールドとの比較において, さらに 日本心理学会ジェンダー部門の歴史を振り返りながら議論を深めたい。

一第3 日 9 月22日 (金) $13: 40 \sim 15: 20$

$4 \mathrm{G} /$ スタジオ 2

\section{SS-086 高齢期の認知機能活性化とライフスタイル：認知症予防介入研 究の最前線}

\author{
企画代表者, 司会者：積山薰 (京都大学) \\ 話題提供者：上田 祥代 (筑波大学) \\ 話題提供者：和田 玲子 (熊本大学) \\ 話題提供者: 田部井賢一 (三重大学) \\ 話題提供者: 野内 類 (東北大学) \\ 指定討論者：佐藤 眞一 (大阪大学)
}

高齢期には記憶力などの認知機能が低下するが，個人差が非常に大きい。どのようなライフスタイル が高齢期の認知機能活性化, ひいては認知症予防に寄与するかを明らかにすることは，心理学者が社会 で果たすべき重要な課題である。現在, ランダム化比較試験による介入研究でこうした要因を明らかに する試みが，世界各地で扔こなわれている。本シンポジウムでは，日本国内の最先端の研究を紹介し， 互いに議論することで，日本からの国際的発信力を高める一助としたい。 